\title{
PUTUSAN MAHKAMAH AGUNG NOMOR 1258K/PID.SUS/2016 TENTANG PUTUSAN TERHADAP PELAKU TINDAK PIDANA KORUPSI DIHUBUNGKAN DENGAN UNDANG-UNDANG REPUBLIK INDONESIA NOMOR 20 TAHUN 2001 TENTANG PERUBAHAN ATAS UNDANG-UNDANG NOMOR 31 TAHUN 1999 TENTANG PEMBERANTASAN TINDAK PIDANA KORUPSI
}

\author{
oleh \\ Amung Koswara \\ H. Riyanto S. Akhmadi
}

\begin{abstract}
ABSTRAK
Korupsi sangat erat hubungannya dengan faktor penyalahgunaan wewenang atau pengaruh yang ada pada kedudukan seseorang sebagai pejabat yang menyimpang dari ketentuan hukum sehingga tindakan tersebut merugikan perekonomian dan keuangan negara. Salah satu peristiwa penyalahgunaan wewenang atau pengaruh yang ada pada kedudukan seseorang sebagai pejabat yang menyimpang yaitu kasus korupsi yang menimpa Drs. H. Alex Tahsin Ibrahim selaku Aparatur Sipil Negara yang ditugaskan pada Pengadilan Negeri Bandung dengan jabatan Wakil Sekretaris. Drs. H. Alex Tahsin Ibrahim merupakan perantara/makelar/calo dalam hal ganti rugi lahan yang menyalahi aturan, berdasarkan putusan Majelis Hakim Pengadilan Tindak Pidana Korupsi pada Pengadilan Negeri Bandung Nomor 126/Pid.Sus-TPK/2015/PN.Bdg Drs. H. Alex Tahsin Ibrahim dinyatakan tidak bersalah, namun setelah diajukan upaya kasasi oleh Jaksa Penuntut Umum dari Kejaksaan Negeri Bandung maka Hakim Mahkamah Agung memberi putusan bersalah terhadap Drs. H. Alex Tahsin Ibrahim berdasarkan Putusan Mahkamah Agung No. 1258K/PID.SUS/2016. Berdasarkan hal tersebut yang menarik untuk diteliti yaitu bagaimanakah pertimbangan hukum hakim dalam Putusan Mahkamah Agung Nomor 1258K/PID.SUS/2016 serta apakah Aparatur Sipil Negara dapat menjadi perantara (makelar) untuk mendapatkan keuntungan. Hasil penelitian menyimpulkan bahwa pertimbangan yuridis pertimbangan Hakim Mahkamah Agung dalam Putusan No. 1258K/PID.SUS/2016 masih kurang utamanya dari pasal-pasal yang digunakan untuk menjerat terdakwa Drs. H. Alex Tahsin Ibrahim. Mahkamah Agung seharusnya juga menggunakan Pasal 5 ayat (2) point j Undang-Undang Nomor 5 Tahun 2014 Tentang Aparatur Sipil Negara, karena terdakwa Drs. H. Alex Tahsin Ibrahim telah menyalahgunakan jabatan untuk mendapat atau mencari keuntungan sendiri. Hakim Mahkamah Agung seharusnya juga mempertimbangkan Pasal 4 point 2 dan 8 Peraturan Pemerintah Nomor 53 Tahun 2010 Tentang Disiplin Pegawai Negeri. Larangan bagi Aparatur Sipil Negara yang menjadi perantara (makelar) untuk mendapatkan keuntungan tersirat dalam Peraturan Pemerintah Nomor 53 Tahun 2010 Tentang Disiplin Pegawai Negeri Aparatur Sipil Negara yang tidak menaati ketentuan menyangkut kewajiban dan larangan dalam peraturan pemerintah tersebut dijatuhi hukuman disiplin, meliputi hukuman disiplin ringan, hukuman disiplin sedang, dan hukuman disiplin berat.
\end{abstract}

Kata Kunci : Aparatur Sipil Negara, Tindak Pidana Korupsi

\section{PENDAHULUAN}

\section{Latar Belakang}

Korupsi bukan sesuatu hal yang baru bagi setiap bangsa namun korupsi merupakan suatu tindak pidana yang unik, multi dimensi dan sangat merusak tatanan kehidupan bermasyarakat, berbangsa dan bernegara. Karakteristik korupsi yang unik, multi dimensi dan destruktif telah menimbulkan pendapat dan penafsiran yang berbeda-beda baik di 
kalangan praktisi hukum maupun teoritisi hukum tentang batasan korupsi sehingga tidaklah mudah menentukan apa yang menjadi sebab utamanya, dan begitu pula tidak mudah menentukan siapa yang menjadi pelaku dan siapa yang menjadi korban. ${ }^{1)}$

Di berbagai belahan dunia, korupsi selalu mendapatkan perhatian yang lebih dibandingkan tindak pidana lainnya. Fenomena ini dapat dimaklumi mengingat dampak negatif yang ditimbulkan oleh tindak pidana ini. Dampak yang ditimbulkan dapat menyentuh berbagai bidang kehidupan. Korupsi merupakan masalah serius, tindak pidana ini dapat membahayakan stabilitas dan keamanan masyarakat, membahayakan pembangunan sosial ekonomi dan juga politik, serta dapat merusak nilai-nilai demokratis dan moralitas karena lambat laun perbuatan ini seakan menjadi budaya. Korupsi merupakan ancaman terhadap cita-cita menuju masyarakat adil dan makmur. ${ }^{2)}$

Pada saat sekarang ini korupsi telah memasuki tahap yang tidak terbatas, dalam melakukan praktik korupsi, para birokrat tidak lagi sekedar ingin memenuhi kebutuhannya, tetapi cenderung menjadi serakah, jalan semakin terbuka lebar kearah itu, para birokrat telah menemukan mekanisme yang sangat efektif untuk dengan cepat mengumpulkan harta sebanyak-banyaknya melalui praktik korupsi, di pihak lain para pengusaha seakan berlomba untuk menjadi pengusaha multi-milyaran. Kedua sisi ini mengalami sinergi yang sangat kompak, di mana satu sama lain saling mendukung dan saling memperkuat, melalui mekanisme ini bermunculan pula pengusaha-pengusaha baru yang berbasis nepotisme dan kolusi. Mereka dengan cepat tumbuh dan membesar secara spektakuler. ${ }^{3)}$

Praktik korupsi dalam kehidupan berbangsa dan bernegara telah menimbulkan banyak kerugian. Kerugian tersebut tidak saja dalam bidang ekonomi, melainkan juga dalam bidang politik, sosial-budaya, maupun keamanan dan juga bidang hukum. Kerugian secara ekonomi misalnya sangat jelas dirasakan, yang tercermin dari tidak optimalnya pembangunan ekonomi yang dijalankan, hasil yang diperoleh dari berbagai aktivitas ekonomi bangsa menjadi jauh lebih kecil dari yang seharusnya dapat dicapai, kemudian muncul pula ketidakadilan ekonomi dalam bentuk perbedaan kesempatan untuk menikmati hasil pembangunan ekonomi atau perbedaan peluang untuk berpartisipasi dalam kegiatan ekonomi. Pemberian hak-hak istimewa atau fasilitas kepada pelaku ekonomi tertentu, dengan menutup peluang bagi pelaku ekonomi lainnya, merupakan contoh dampak dari korupsi yang membatasi partisipasi masyarakat dalam bidang ekonomi, pemberian hak istimewa ini justru seringkali menimbulkan ketidak efisienan dalam ekonomi, sebagai akibat dari adanya persaingan yang tidak jujur. ${ }^{4)}$

Korupsi dalam bidang politik, praktik korupsi menimbulkan diskriminasi pelayanan publik ataupun diskriminasi penghargaan terhadap hak-hak politik masyarakat, hal ini dapat terjadi karena adanya upaya memanfaatkan korupsi untuk kepentingan politik, praktek korupsi terutama yang terjadi dalam birokrasi pemerintahan, lebih mudah dilakukan oleh para penguasa. Terkaitnya mayoritas mesin birokrasi dengan satu kekuatan politik tertentu, telah membuka peluang praktik korupsi, yang sebagian digunakan untuk mendukung afiliasi politiknya, praktek ini seakan menjadi sesuatu yang legal, karena dianggap untuk kepentingan satu korp. ${ }^{5)}$

1) Romli Atmasasmita, Reformasi Hukum, HAM dan Penegakan Hukum, Mandar Maju, Bandung, 2001, hlm. 74 .

2) Evi Hartanti, Tindak Pidana Korupsi, Sinar Grafika, Jakarta, 2005, hlm. 1.

3) Darli Darwis, Birokrasi di Indonesia Sangat Rawan KKN, Aditya Media, Yogyakarta, 1999, hlm. 60

4) Edy Suwandi Hamid, Korupsi, Kolusi dan Nepotisme di Indonesia, Aditya Media, Yogyakarta, 1999, hlm. 2.

5) Ibid 
Korupsi dalam bidang hukum telah merusak sendi-sendi keadilan, yang saat ini menjadi barang mewah dan mahal, yang hanya bisa didapat oleh mereka yang mempunyai uang dan berkuasa. Dalam praktik peradilan, pasal undang-undang telah dijadikan komoditas yang diperdagangkan oleh orang atau lembaga yang seharusnya memberi keadilan kepada pencari keadilan. Ironisnya, rakyat (terutama di tingkat bawah) dalam keadaan tidak berdaya dengan terpaksa harus membeli keadilan berapapun harganya, dengan segala upaya dan daya yang ada pada diri mereka. Maka tindakan korupsi seorang penguasa akan melahirkan koruptor-koruptor di kalangan rakyat. Dan ini terjadi tidak hanya pada kasus-kasus berat tetapi juga pada kasus-kasus ringan namun bersifat masif. Misalnya, praktik damai dengan memberi imbalan (sogok) yang dilakukan pelanggar aturan lalu lintas ketika akan ditilang oleh petugas yang berwenang. Di samping itu, sering seorang petugas meminta imbalan kepada masyarakat, padahal dia telah digaji oleh negara dalam menjalankan tugasnya memberikan pelayanan kepada masyarakat. ${ }^{6}$

\section{Identifikasi Masalah}

Berdasarkan latar belakang pemilihan kasus dan kasus posisi yang telah diterangkan di Bab I, Penulis mengidentifikasikan permasalahan sebagai berikut :

1. Bagaimanakah Pertimbangan Hukum Hakim Dalam Putusan Mahkamah Agung Nomor 1258K/PID.SUS/2016?

2. Apakah Aparatur Sipil Negara Dapat Menjadi Perantara (Makelar) Untuk Mendapatkan Keuntungan?

6) https://www.obsessionnews.com/korupsi-dampak-dan-penanggulangannya/, diakses pada tanggal 15 Agustus 2019 pukul 14.25 WIB 


\section{TINJAUAN PUSTAKA}

Korupsi di Indonesia telah memasuki tahap yang sangat kompleks, dan telah melanda seluruh lapisan pemerintahan, mulai dari tingkat yang paling rendah hingga ke tingkat yang paling tinggi, demikian pula halnya pada semua lapisan masyarakat, singkatnya kata korupsi telah menjadi sistem di negeri ini bahkan telah menjadi cara hidup kita sehari-hari, semua institusi telah terkotori oleh praktik korupsi, sehingga sangat sulit menemukan institusi pemerintahan yang terbebas dari cengkeraman korupsi.

Menurut Darlis Darwis :

"Saat ini korupsi telah memasuki tahap yang tidak terbatas, dalam melakukan praktik korupsi, para birokrat tidak lagi sekedar ingin memenuhi kebutuhannya, tetapi cenderung menjadi serakah. Jalan semakin terbuka lebar untuk menuju kearah itu para birokrat telah menemukan mekanisme yang sangat efektif untuk dengan cepat mengumpulkan harta sebanyak-banyaknya melalui praktik korupsi."7)

Fockema Andreae memberikan deskripsi bahwa, "kata korupsi berasal dari bahasa latin corruption atau corroptus, Eropa seperti Inggris corruption, corrupt, Perancis corruption, Belanda corruptive dan Indonesia korupsi yang secara harafiah adalah kebusukan, keburukan, kebejatan, ketidakjujuran, dapat disuap, tidak bermoral, penyimpangan dari kesucian". ${ }^{8)}$ Sedangkan istilah korupsi oleh Poerwadarminta "korupsi ialah perbuatan yang buruk seperti penggelapan uang, penerimaan uang sogok dan sebagainya". ${ }^{9}$

Pengertian masyarakat umum terhadap kata korupsi adalah berkenaan dengan keuangan negara yang dimiliki secara tidak sah (haram). Dalam Kamus Besar Bahasa Indonesia korupsi diartikan dengan penyelewengan atau penggelapan (uang negara atau perusahaan dan sebagainya) untuk keuntungan pribadi atau orang lain. Sehubungan dengan korupsi Fathurrahman Djamil berpendapat bahwa : "Korupsi adalah suatu tindakan baik berupa penyelewengan hak, kedudukan, wewenang atau jabatan yang dilakukan untuk mengutamakan kepentingan dan keuntungan pribadi, menyalahgunakan (mengkhianati) 'amanah' rakyat dan bangsa, mengikuti hawa nafsu serakah untuk memperkaya diri dan mengabaikan kepentingan umum", ${ }^{10)}$ kemudian Fathurrahman Djamil menambahkan bahwa ada delapan ciri pokok korupsi, yaitu :11)

1. penipuan terhadap pemerintah, swasta, atau masyarakat.

2. melalaikan kepentingan umum demi kepentingan khusus.

3. dilakukan dengan rahasia/lewat persekongkolan kolektif.

4. melibatkan lebih dari satu pihak.

5. ada kewajiban dan keuntungan bersama.

6. terpusatnya kegiatan korupsi antara yang menghendaki keputusan pasti dan yang berwenang mempengaruhinya.

7. ada usaha menutup-nutupi.

8. berfungsi gandanya sang koruptor.

Selanjutnya korupsi dapat diklasifikasikan menjadi tujuh macam, yaitu : ${ }^{12)}$

7) Darli Darwis., Op.Cit., hlm. 57

8) Fockema Andreae., dalam Andi Hamzah, Pemberantasan Korupsi Melalui Hukum Pidana Nasional dan Internasional, Raja Grafindo Persada, Jakarta, 2005, hlm. 5.

9) Poerwadarminta., dalam Andi Hamzah., Ibid

10) Fathurrahman Djamil, KKN dalam Perspektif Hukum dan Moral Islam, Aditya Media, Yogyakarta, 1999, hlm.106.

11) Ibid

${ }^{12)}$ Syed Husain Alatas., dalam Edy Suwandi Hamid., Op.Cit., hlm.107. 
1. Korupsi transaksi adalah korupsi yang bertolak dari sikap bisnis dalam transaksi sosial, seperti dalam peribahasa "ada ubi ada talas, ada budi ada balas".

2. Korupsi ekstrosi adalah korupsi yang merupakan pemerasan dan/atau penghisapan berupa pemaksaan korban agar melakukan "penyogokan", jika tidak mau melakukan maka ia (korban) akan lebih "celaka".

3. Korupsi defensif adalah korupsi membela diri, yaitu tindak penyuapan sebagai bagian dari pembelaan dirinya.

4. Korupsi investif adalah korupsi ini terjadi jika ada pengusaha atau pejabat "memelihara" pejabat lain dengan hampir memenuhi apa saja yang jadi permintaannya, sepertinya tanpa maksud tertentu. Tetapi yang menjadi harapannya ialah meminta perlindungan atau jasa baik kapan saja tiba saatnya ia butuhkan, misalnya saat menghadapi kesulitan, kecurangannya diperkarakan dan sebagainya.

5. Korupsi nepotis adalah korupsi mengenai penunjukan secara tidak sah teman, sanak saudara untuk memberi pekerjaan dan/atau pemborongan pekerjaan, kemudahan-kemudahan atau uang secara bertentangan dengan norma dan peraturan yang berlaku.

6. Korupsi otogenik adalah korupsi karena jabatan dan wewenang, misalnya seseorang membuat keputusan atau peraturan yang bermanfaat dan berguna untuk dirinya sendiri.

7. Korupsi suportif adalah korupsi yang merupakan "pembackingan" suatu tindakan korup dengan harapan memperoleh keuntungan dari pelaku utama.

Korupsi merupakan tindakan yang mengandung unsur pengkhianatan kepercayaan, penyuapan, pembackingan, pemaksaan (tekanan-tekanan dari pihak yang lebih berkuasa), nepotis dan despotis, pengutamaan kepentingan pribadi, pembudayaan bagi komisi, penetapan keputusan atau kebijakan sepihak (menguntungkan pihak tertentu), intransparansi, pemerasan dan penggelapan, penyalahgunaan wewenang, kekuasaan, jabatan, kedudukan dan merugikan orang lain atau umum, serta melanggar aturan normatif dan moral kemanusiaan.

Pelaku korupsi adalah orang-orang terdidik dan relatif memiliki jabatan (birokrasi), pada asasnya setiap korupsi di birokrasi mana saja sifatnya sama, yakni pemanfaatan jabatan oleh oknum pejabat untuk menguntungkan diri sendiri atau kelompoknya, dalam hal mana perbuatan tersebut menyimpang dari bunyi sumpah jabatan dan hukum yang berlaku. Ditinjau dari segi keuangan yang dirugikan, korupsi ini pada galibnya ada dua yaitu merugikan keuangan negara dan merugikan keuangan masyarakat dalam kategori individual. ${ }^{13)}$

Langkah-langkah pembentukan hukum positif guna menghadapi masalah korupsi di Indonesia telah dilakukan selama beberapa masa perjalanan sejarah dan melalui beberapa masa perubahan peraturan perundang-undangan. Pada masa yang terdahulu untuk menjerat pelaku tindak pidana korupsi menggunakan ketentuan-ketentuan yang terdapat dalam KUHP, pada masa itu tindak pidana korupsi identik dengan tindak pidana jabatan yaitu suatu perbuatan oleh pejabat dalam menjalankan jabatannya.

Tindak pidana jabatan merupakan sejumlah tindak pidana-tindak pidana tertentu, yang hanya dapat dilakukan oleh orang-orang yang mempunyai sifat sebagai pegawai negeri. Agar tindak pidana-tindak pidana yang dilakukan oleh para pegawai negeri itu dapat disebut sebagai tindak pidana-tindak pidana jabatan, maka tindak pidana-tindak

13) Ronny Rahman Nitibaskara, Tegakkan Hukum Gunakan Hukum, PT Kompas Media Nusantara, Jakarta, 2007, hlm. 26. 
pidana tersebut harus dilakukan oleh para pegawai negeri yang bersangkutan dalam menjalankan tugas jabatan mereka masing-masing. ${ }^{14)}$

Tindak pidana jabatan di dalam KUHP yang berkaitan dengan tindak pidana korupsi terdapat dalam Bab XXVIII KUHP yaitu khususnya terhadap perbuatan penggelapan oleh pegawai negeri (Pasal $415 \mathrm{KUHP}$ ), membuat palsu atau memalsukan (Pasal 416 KUHP), menerima pemberian atau janji (Pasal 418, 419, dan 420 KUHP) serta menguntungkan diri sendiri atau orang lain secara melawan hukum (Pasal 423, 425 dan 435 KUHP). Pada hakikatnya, ketentuan-ketentuan tindak pidana korupsi itu ternyata kurang efektif dalam menanggulangi korupsi. Tindak pidana korupsi yang dapat dikenakan dalam pasal-pasal KUHP saat itu dirasakan kurang bahkan tidak efektif menghadapi gejala-gejala korupsi saat itu. Maka, dirasakan perlu adanya peraturan yang dapat lebih memberi keleluasaan kepada penguasa untuk bertindak terhadap pelaku-pelakunya. ${ }^{15)}$

KUHP pada masa itu kurang efektif di dalam menjerat pelaku-pelaku tindak pidana korupsi atau yang pada saat itu dikenal dengan tindak pidana jabatan. Kemudian dibentuklah Undang-Undang Nomor 24 Prp Tahun 1960 Tentang Pengusutan, Penuntutan, dan Pemeriksaan Tindak Pidana Korupsi. ${ }^{16)}$

Upaya pemberantasan tindak pidana korupsi dengan menggunakan UndangUndang Nomor 24 Prp Tahun 1960 Tentang Pengusutan, Penuntutan, dan Pemeriksaan Tindak Pidana Korupsi pada masa undang-undang ini digunakan tampaknya kurang berhasil. Berdasarkan kenyataan di lapangan, banyak ditemukan hal-hal yang tidak sesuai, antara lain: ${ }^{17)}$

1. Adanya perbuatan yang merugikan keuangan atau perekonomian negara yang menurut perasaan keadilan masyarakat harus dituntut dan dipidana, tidak dapat dipidana karena tidak adanya rumusan tindak pidana korupsi yang berdasarkan kejahatan atau pelanggaran yang dilakukan tersebut;

2. Pelaku tindak pidana korupsi hanya ditujukan kepada pegawai negeri, tetapi kenyataannya orang-orang yang bukan pegawai negeri yang menerima tugas atau bantuan dari suatu badan negara, dapat melakukan perbuatan tercela seperti yang dilakukan pegawai negeri;

3. Perlu diadakan ketentuan yang mempermudah pembuktian dan mempercepat proses hukum acara yang berlaku tanpa tidak memperhatikan hak asasi tersangka atau terdakwa.

Berdasarkan berbagai pertimbangan yang dilakukan oleh pemerintah maka dilakukan penyempurnaan terhadap Undang-Undang Nomor 24 Prp Tahun 1960 sehingga dicabut dan diganti dengan Undang-Undang Nomor 3 Tahun 1971 Tentang Pemberantasan Tindak Pidana Korupsi. Namun pada perkembangan selanjutnya Undang-Undang Nomor 3 Tahun 1971 mengalami penyempurnaan karena Undang-Undang Nomor 3 Tahun 1971 sudah tidak sesuai lagi dengan perkembangan kebutuhan hukum dalam masyarakat dan perlu diganti dengan undang-undang pemberantasan tindak pidana korupsi yang baru sehingga diharapkan lebih efektif dalam mencegah dan memberantas tindak pidana korupsi. Kemudian pemerintah pada masa reformasi ini membuat Undang-Undang Nomor 31

14) Lilik Mulyadi, Tindak Pidana Korupsi di Indonesia Normatif, Teoritis, Praktik dan Masalahnya, Alumni, Bandung, 2007, hlm. 155.

15) Ibid., hlm. 156.

16) Andi Hamzah, Bunga Rampai Hukum Pidana dan Acara Pidana, Ghalia Indonesia, Jakarta, 1986, hlm.204

17) Evi Hartanti, Tindak Pidana Korupsi (Edisi Kedua), Sinar Grafika, Jakarta, 2007, hlm.33. 
Tahun 1999 Tentang Pemberantasan Tindak Pidana Korupsi, yang kemudian diubah kembali dengan Undang-Undang Nomor 20 Tahun 2001 Tentang Perubahan atas UndangUndang Nomor 31 Tahun 1999 Tentang Pemberantasan Tindak Pidana Korupsi.

Pengertian tindak pidana korupsi menurut Undang-Undang Nomor 31 Tahun 1999 Tentang Pemberantasan Tindak Pidana Korupsi juncto Undang-Undang Nomor 20 Tahun 2001 Tentang Perubahan Atas Undang-Undang Nomor 31 Tahun 1999 Tentang Pemberantasan Tindak Pidana Korupsi, itu dapat dibedakan dari 2 segi, yaitu korupsi aktif dan korupsi pasif. Adapun yang dimaksud dengan korupsi aktif adalah :

1. Secara melawan hukum memperkaya diri sendiri atau orang lain atau suatu korporasi yang dapat merugikan keuangan atau perekonomian Negara.

2. Dengan tujuan menyalahgunakan kewenangan, kesempatan atau sarana karena jabatan atau kedudukannya.

3. Memberi hadiah atau janji dengan mengingat kekuasaan atau wewenang pada jabatan atau kedudukannya.

4. Percobaan, pembantuan atau permufakatan jahat.

5. Memberi atau menjanjikan sesuatu dengan maksud supaya berbuat atau tidak berbuat.

6. Memberi sesuatu yang bertentangan dengan kewajibannya.

7. Memberi janji.

8. Sengaja membiarkan perbuatan curang.

9. Sengaja menggelapkan uang atau surat berharga.

Sedangkan korupsi pasif, antara lain :

1. Menerima pemberian atau janji karena berbuat atau tidak berbuat.

2. Menerima penyerahan atau keperluan dengan membiarkan perbuatan curang.

3. Menerima pemberian hadiah atau janji.

4. Adanya hadiah atau janji diberikan untuk menggerakkan agar melakukan sesuatu.

5. Menerima gratifikasi yang diberikan berhubungan dengan jabatannya.

\section{PEMBAHASAN}

Awalnya Pengadilan Tindak Pidana Korupsi pada Pengadilan Negeri Bandung, yang berdasarkan Putusan No. 126/Pid.Sus-TPK/2015/PN.Bdg Majelis Hakim Pengadilan Tindak Pidana Korupsi pada Pengadilan Negeri Bandung menyatakan terdakwa Drs. H. Alex Tahsin Ibrahim tidak bersalah dan membebaskan terdakwa dari seluruh dakwaan penuntut umum, hal tersebut berdasarkan pertimbangan Majelis Hakim Pengadilan Tindak Pidana Korupsi pada Pengadilan Negeri Bandung yang menyatakan bahwa perbuatan terdakwa Drs. H. Alex Tahsin Ibrahim tidak memenuhi semua unsur dakwaan kesatu primair dan kesatu subsidair, atau dakwaan kedua, atau dakwaan ketiga, dimana pada pokoknya Jaksa Penuntut Umum mendakwa terdakwa Drs. H. Alex Tahsin Ibrahim telah menerima uang sebesar Rp. 400.000.000,00 dari ahli waris Idji Hatadji sebagai imbalan atas jasa terdakwa Drs. H. Alex Tahsin Ibrahim dalam upaya pencairan dana ganti rugi tanah SMA 22 Kota Bandung.

Terdakwa Drs. H. Alex Tahsin Ibrahim memproleh uang sebesar Rp 400.000.000,00 (empat ratus juta rupiah) dan Olih Darmawan Hatadji bersama-sama dengan Rachmat Affandi Hatadji memperoleh uang sebesar Rp 6.963.925.000,00 (enam miliar sembilan ratus enam puluh tiga juta sembilan ratus dua puluh lima ribu rupiah). Terdakwa Drs. H. Alex Tahsin Ibrahim melakukan perbuatan melawan hukum secara 
bersama-sama dengan Olih Darmawan Hatadji, Rachmat Affandi Hatadji dan Didi Rismunadi Kabid Pemberdayaan Aset Dinas Pengelolaan Keuangan dan Aset Daerah (DPKAD) Pemerintah Kota Bandung (dinyatakan bersalah oleh Pengadilan Tipikor pada Pengadilan Negeri Bandung) merugikan keuangan negara sebesar Rp 7.363.925.000,00 (tujuh miliar tiga ratus enam puluh tiga juta sembilan ratus dua puluh lima ribu rupiah).

Perbuatan terdakwa Drs. H. Alex Tahsin Ibrahim bersama-sama dengan Olih Darmawan Hatadji, Rachmat Affandi Hatadji dan Didi Rismunadi, yang menyebabkan Bendahara Pengeluaran DPKAD Kota Bandung kemudian mengeluarkan Surat Permintaan Pembayaran (SPP) Nomor 991/0203/1.20.05.01/LS/2013 tanggal 13 Desember 2013, Surat Perintah Membayar Nomor SPM: 931/0203/1.20.05.01/LS/2013 tanggal 20 Desember 2013 yang ditandatangani oleh Didi Rismunadi, selaku Kuasa Pengguna Anggaran dan Surat Perintah Pencairan Dana (SP2D) Nomor 957/13549/1.20.05.01/BL/2013 tanggal 27 Desember 2013 dan membayar kepada Olih Darmawan Hatadji setelah dikurangi pajak menjadi sebesar Rp7.363.925.000,00 (tujuh miliar tiga ratus enam puluh tiga juta sembilan ratus dua puluh lima ribu rupiah) menyebabkan terjadinya kerugian keuangan negara/Pemerintah Kota Bandung sebagai perbuatan korupsi, dan oleh karena itu terdakwa Drs. H. Alex Tahsin Ibrahim harus dipersalahkan dan bertanggungjawab akibat dari perbuatannya.

Fakta hukum yang terungkap tersebut menerangkan bahwa perbuatan terdakwa Drs. H. Alex Tahsin Ibrahim memalsukan Surat Pengadilan Negeri Bandung Nomor W11.U1/1999/AT.02.02/V/2013 tanggal Mei 2013 yang dijadikan dasar pembayaran ganti rugi tanah seluas $4.180 \mathrm{~m} 2$, merupakan perbuatan melawan hukum yang bertentangan dengan kewajiban hukum terdakwa Drs. H. Alex Tahsin Ibrahim, yang seharusnya tidak dilakukan atau patut diketahuinya, bahwa perbuatan tersebut telah bertentangan dengan ketentuan Pasal 263 Ayat (1) KUHP. Perbuatan terdakwa Drs. H. Alex Tahsin Ibrahim yang melawan hukum tersebut telah memperkaya diri terdakwa Drs. H. Alex Tahsin Ibrahim sendiri atau orang lain, yaitu bertambahnya kekayaan terdakwa Drs. H. Alex Tahsin Ibrahim sebesar Rp 400.000.000,00 (empat ratus juta rupiah) dan Olih Darmawan Hatadji dan kawan-kawannya sebesar Rp 7.363.925.000,00 (tujuh miliar tiga ratus enam puluh tiga juta sembilan ratus dua puluh lima ribu rupiah). Akibat perbuatan terdakwa Drs. H. Alex Tahsin Ibrahim tersebut mempunyai hubungan kausal secara yuridis yang mengakibatkan adanya kerugian keuangan negara/daerah sebesar Rp 7.363.925.000,00 (tujuh miliar tiga ratus enam puluh tiga juta sembilan ratus dua puluh lima ribu rupiah).

Mahkamah Agung juga mempertimbangkan hal-hal yang memberatkan dan yang meringankan terdakwa Drs. H. Alex Tahsin Ibrahim. Hal-hal yang memberatkan antara lain terdakwa Drs. H. Alex Tahsin Ibrahim sebagai Pegawai Negeri Sipil (PNS) pada institusi pengadilan tidak memberi contoh yang baik dalam penegakkan hukum, perbuatan terdakwa Drs. H. Alex Tahsin Ibrahim sebagai Pegawai Negeri Sipil (PNS) tidak mendukung pemerintah dalam upaya pemberantasan tindak pidana korupsi. Hal-hal yang meringankan antara lain terdakwa Drs. H. Alex Tahsin Ibrahim mempunyai tanggungan keluarga, terdakwa Drs. H. Alex Tahsin Ibrahim telah mengembalikan sebagian uang hasil perbuatannya sebesar Rp 300.000.000,00 (tiga ratus juta rupiah) melalui Kejaksaan Negeri Bandung.

Berdasarkan pertimbangan tersebut di atas, Hakim Mahkamah Agung dalam memutus perkara pada Putusan No. 1258K/PID.SUS/2016 telah menggunakan pertimbangan yuridis dan non-yuridis. Di mana pertimbangan yuridis didasarkan pada fakta-fakta yang terungkap di persidangan dan oleh undang-undang merupakan hal-hal yang harus dimuat dalam putusan misalnya saja pertimbangan terhadap dakwaan jaksa penuntut umum, keterangan saksi, keterangan ahli, barang bukti, keterangan terdakwa Drs. 
H. Alex Tahsin Ibrahim dan lain sebagainya. Sedangkan pertimbangan non-yuridis didasarkan pada latar belakang terdakwa Drs. H. Alex Tahsin Ibrahim, akibat yang ditimbulkan dari perbuatan terdakwa Drs. H. Alex Tahsin Ibrahim, serta kondisi atau kemampuan bertanggung jawab terdakwa Drs. H. Alex Tahsin Ibrahim. Di mana pertimbangan non-yuridis biasanya terdapat pada hal-hal yang meringankan dan hal-hal yang memberatkan yang terdapat dalam putusan.

Aparatur Sipil Negara yang tidak menaati ketentuan menyangkut kewajiban dan larangan dalam peraturan pemerintah tersebut dijatuhi hukuman disiplin, meliputi hukuman disiplin ringan, hukuman disiplin sedang, dan hukuman disiplin berat. Hukuman disiplin ringan terdiri dari teguran lisan, teguran tertulis, dan pernyataan tidak puas secara tertulis. Hukuman disiplin sedang meliputi penundaan kenaikan gaji berkala selama 1 tahun, penundaan kenaikan pangkat selama 1 tahun, dan penurunan pangkat setingkat lebih rendah selama 1 tahun. Sedangkan hukuman disiplin berat terdiri dari penurunan pangkat setingkat lebih rendah selama 3 tahun, pemindahan dalam rangka penurunan jabatan setingkat lebih rendah, pembebasan dari jabatan, pemberhentian dengan hormat tidak atas permintaan sendiri sebagai PNS, dan pemberhentian tidak dengan hormat sebagai PNS.

Tolak ukur kesuksesan pemberantasan korupsi tidaklah ditentukan dari seberapa banyaknya program pemerintah untuk pemberantasan korupsi atau pun seberapa bagusnya mutu peraturan yang mengatur pemberantasan korupsi tersebut, melainkan tolak ukur kesuksesan pemberantasan korupsi dapat dilihat dari dihindarinya perilaku koruptif dari para biroktrat, aparatur sipil negara, dan para penegak hukum dari pemerintahan tersebut. Idealnya, pemberantasan korupsi tersebut harus dimulai dari diri para penegak hukum itu sendiri. Sebab apalagi yang dapat kita harapkan jika para penegak hukum sendirilah yang melakukan dan membudayakan korupsi.

Aparatur Sipil Negara terbilang masih rentan terhadap kasus suap yang mengarah pada korupsi. Faktor utama korupsi di kalangan Aparatur Sipil Negara adalah pola rekruitmen, promosi, rotasi, dan mutasi yang salah. Penempatan Aparatur Sipil Negara bukan karena kompetensi dan integritas, tapi karena kedekatan personal dengan atasan merupakan salah satu faktor kasus suap atau gratifikasi yang mengarah pada korupsi. Pola, aktor, dan harga dari sebuah perdagangan "pengaruh" masih ada di lingkungan Aparatur Sipil Negara. Selama masih adanya peminat, maka semakin besar pula peluang untuk menjual "pengaruh" tersebut.

Pola lama Aparatur Sipil Negara yang lebih mendahulukan kerabat dan orang terdekat yang telah terbentuk itu sulit untuk ditumpas. Padahal fungsi Aparatur Sipil Negara yang semula disebut Pegawai Negeri Sipil harus ditingkatkan. Aparatur Sipil Negara itu memiliki tanggungjawab lain sebagai agen pemerintah untuk menciptakan kepercayaan masyarakat kepada pemerintah. Salah satu caranya dengan menolak suap, korupsi dan laporan keuangan dalam bentuk cyber public. 


\section{PENUTUP}

\section{Kesimpulan}

Pertimbangan non-yuridis yang dilakukan Hakim Mahkamah Agung dalam Putusan No. 1258K/PID.SUS/2016 telah sesuai. Namun, dari segi pertimbangan yuridis pertimbangan Hakim Mahkamah Agung dalam Putusan No. 1258K/PID.SUS/2016 masih kurang utamanya dari pasal-pasal yang digunakan untuk menjerat terdakwa Drs. H. Alex Tahsin Ibrahim. Mahkamah Agung seharusnya juga menggunakan Pasal 5 ayat (2) point $\mathrm{j}$ Undang-Undang Nomor 5 Tahun 2014 Tentang Aparatur Sipil Negara, karena terdakwa Drs. H. Alex Tahsin Ibrahim telah menyalahgunakan jabatan untuk mendapat atau mencari keuntungan sendiri. Hakim Mahkamah Agung seharusnya juga mempertimbangkan Pasal 4 point 2 dan 8 Peraturan Pemerintah Nomor 53 Tahun 2010 Tentang Disiplin Pegawai Negeri. Larangan bagi Aparatur Sipil Negara yang menjadi perantara (makelar) untuk mendapatkan keuntungan tersirat dalam Peraturan Pemerintah Nomor 53 Tahun 2010 Tentang Disiplin Pegawai Negeri Aparatur Sipil Negara yang tidak menaati ketentuan menyangkut kewajiban dan larangan dalam peraturan pemerintah tersebut dijatuhi hukuman disiplin, meliputi hukuman disiplin ringan, hukuman disiplin sedang, dan hukuman disiplin berat.

\section{Saran}

Supaya Aparatur Sipil Negara harus bisa menjaga perilakunya untuk tidak terjebak kepada perbuatan yang salah. Apabila terjadi tingkah laku Aparatur Sipil Negara yang berprilaku koruptif, maka harus ditindaklanjuti oleh aparat penegak hukum atau Komisi Aparat Sipil Negara. Jual beli ini "pengaruh" awal tertularnya birokrasi oleh korupsi. Menyebabkan langkah awal adanya mahar birokrasi kepada politisi.

\section{DAFTAR PUSTAKA}

Andi Hamzah, Bunga Rampai Hukum Pidana dan Acara Pidana, Ghalia Indonesia, Jakarta, 1986

Pemberantasan Korupsi Melalui Hukum Pidana Nasional dan Internasional, Raja Grafindo Persada, Jakarta, 2005

Darli Darwis, Birokrasi di Indonesia Sangat Rawan KKN, Aditya Media, Yogyakarta, 1999

Edy Suwandi Hamid, Korupsi, Kolusi dan Nepotisme di Indonesia, Aditya Media, Yogyakarta, 1999

Evi Hartanti, Tindak Pidana Korupsi, Sinar Grafika, Jakarta, 2005

Lilik Mulyadi, Tindak Pidana Korupsi di Indonesia Normatif, Teoritis, Praktik dan Masalahnya, Alumni, Bandung, 2007

Fathurrahman Djamil, KKN dalam Perspektif Hukum dan Moral Islam, Aditya Media, Yogyakarta, 1999

Romli Atmasasmita, Reformasi Hukum, HAM dan Penegakan Hukum, Mandar Maju, Bandung, 2001

Ronny Rahman Nitibaskara, Tegakkan Hukum Gunakan Hukum, PT Kompas Media Nusantara, Jakarta, 2007 